\title{
LITERATURE REVIEW : HUBUNGAN AKTIVITAS FISIK DENGAN DISMENORE PRIMER PADA REMAJA
}

\author{
Santha Eliska Br Gurusinga ${ }^{*}$, Austin Bertilova Carmelita ${ }^{2}$, Arif Rahman Jabal ${ }^{3}$, Dian Mutiasari ${ }^{4}$, \\ Agnes Frethernety ${ }^{5}$ \\ 1. Fakultas Kedokteran Universitas Palangka Raya, Palangka Raya, Kalimantan Tengah, \\ Indonesia
}

2. Departemen Gigi dan Mulut Fakultas Kedokteran Universitas Palangka Raya, Palangka Raya, Kalimantan Tengah, Indonesia

3. Departemen Parasitologi Fakultas Kedokteran Universitas Palangka Raya, Palangka Raya, Kalimantan Tengah, Indonesia

4. Departemen Ilmu Kesehatan Masyarakat Fakultas Kedokteran Universitas Palangka Raya, Palangka Raya, Kalimantan Tengah, Indonesia

5. Departemen Farmakoterapi Fakultas Kedokteran Universitas Palangka Raya, Palangka Raya, Kalimantan Tengah, Indonesia

*e-mail: santhaeliska123@gmail.com

\begin{abstract}
ABSTRAK
Latar Belakang : Dismenore primer sering terjadi pada remaja karena hormon yang dihasilkan belum stabil. Prevalensi dismenore primer pada remaja Indonesia adalah 60-75\%. Aktivitas fisik adalah salah satu faktor resiko terjadinya dismenore primer. Aktivitas fisik remaja menurun setiap tahun. Tujuan : Literature review ini bertujuan menganalisis hubungan antara aktivitas fisik dengan dismenore primer pada remaja. Metode: Mesin pencarian data yang digunakan adalah Google Scholar, Science Direct, dan Garuda. Jurnal yang dikumpulkan adalah jurnal nasional dan internasional sejak tahun 2015-2020. Pencarian artikel penelitian ini menggunakan kriteria inklusi dan eksklusi. Literature review ini menggunakan 15 jurnal nasional dan 8 jurnal internasional. Hasil : Jurnal yang menyatakan aktivitas fisik berhubungan dengan dismenore primer pada remaja ditemukan sebanyak 21 jurnal, sedangkan 2 jurnal menyatakan tidak berhubungan. Aktivitas fisik meningkatkan endorphin, memperlancar aliran darah kebagian genital, dan meningkatkan vasodilatasi pembuluh darah. Kesimpulan: Aktivitas fisik berhubungan dengan dismenore primer pada remaja.
\end{abstract}

Kata kunci : Aktivitas Fisik, Dismenore Primer, Remaja

\begin{abstract}
Background: Dysmenorrhea often occurs in adolescents because the hormones produced are not yet stable. The prevalence of primary dysmenorrhea in Indonesian adolescents is 60-75\%. Physical activity is one of the primary risk factors for damage. Youth physical activity decreases every year. Purpose: This literature review aims to analyze the relationship between physical activity and primary dysmenorrhea in adolescents. Methods: The data search engines used were Google Scholar, Science Direct, and Garuda. The journals collected are national and international journals from 2015-2020. Search for research articles using inclusion and exclusion criteria. The literature review uses 15 national journals and 8 international journals. Results: The journals that stated physical activity related to primary in adolescents were found as many as 21 journals, while 2 journals that were not related. Physical activity increases endorphins, increases blood flow to the genitals, and increases vasodilation of blood vessels. Conclusion: Physical activity is related to primary in adolescents.
\end{abstract}

Keywords: Physical Activity, Primary Dysmenorrhea, Adolescents 


\section{A. PENDAHULUAN}

Berdasarkan data World Health Organization (WHO), penelitian tentang dismenore yang telah dilakukan oleh berbagai negara melaporkan bahwa kejadian dismenore primer lebih tinggi dibandingkan dengan dismenore sekunder yaitu lebih dari $50 \%$. Prevalensi dismenore pada wanita di dunia masih cukup besar yaitu sebesar 1.769.425 jiwa (90\%) dan terdapat dismenore berat sebesar 10-15\%. ${ }^{1}$ Angka kejadian dismenore primer di Indonesia adalah sekitar 54,89\% sedangkan sisanya penderita dengan dismenore sekunder. 2,3 Berdasarkan penelitian di India menyatakan bahwa prevalensi dismenore pada remaja (rentang usia 10-19 tahun) di India sekitar 73,9\%. ${ }^{4}$ Dismenore primer juga dialami oleh $60-75 \%$ remaja di Indonesia. ${ }^{5}$ Tingginya angka kejadian dismenore primer pada remaja menyebabkan dampak buruk, salah satunya adalah ketidakhadiran sekolah serta menjadi masalah kesehatan yang perlu diperhatikan pada remaja perempuan. ${ }^{6,7,8,9}$ Dismenore primer juga menyebabkan wanita memerlukan resep obat sebagai usaha mengurangi rasa nyeri, menurunkan kualitas hidup, konsentrasi dan motivasi belajar remaja. ${ }^{10}$

Dismenore primer ditandai dengan nyeri yang dirasakan selama beberapa jam pada saat bersamaan dengan permulaan menstruasi namun tanpa adanya kelainan pada alat-alat genital. ${ }^{11}$ Wanita yang sudah memasuki masa pubertas akan mengalami tanda-tanda pubertas dalam tubuhnya, salah-satunya adalah menstruasi. Menstruasi dikenal dengan perdarahan rahim yang berlangsung secara periodik dan siklik. Pelepasan (deksuamasi) endometrium akibat hormon ovarium (estrogen dan progesteron) yang mengalami perubahan kadar pada akhir siklus ovarium mengakibatkan menstruasi, biasanya dimulai pada hari ke-14 setelah ovulasi. ${ }^{12}$ Selama proses menstruasi, wanita dapat mengalami kram rahim bersaman dengan permulaan menstruasi dan berlangsung beberapa jam hingga mencapai puncak nyeri yang disebut dismenore. ${ }^{11}$ Dismenore primer hampir selalu pertama kali terjadi pada wanita yang berusia 20 tahun atau kurang dari 20 tahun setelah haid pertama. ${ }^{13}$

Faktor resiko dismenore primer adalah menarche dini dengan usia kurang dari 12 tahun, jarang atau tidak pernah olahraga, siklus dan lama haid lebih dari normal (7 hari). Selain itu, riwayat keluarga, stres, kebiasaan lain seperti mengonsumsi makanan junkfood atau makanan cepat saji, merokok, dan mengkonsumsi alkohol juga dapat menyebabkan dismenore primer. ${ }^{14}$ Aktivitas fisik yang kurang juga menjadi salah satu faktor resiko terjadinya dismenore primer. Hal tersebut dikarenakan ketika terjadi dismenore, oksigen tidak dapat tersalurkan ke pembuluh-pembuluh darah di organ reproduksi yang saat ini terjadi vasokontriksi sehingga menyebabkan timbulnya rasa nyeri. ${ }^{2}$

Aktivitas fisik pada remaja saat ini mayoritas mengalami penurunan. Penurunan aktivitas pada remaja ini berlangsung setiap tahunnya. Remaja mengalami perubahan tempat dan lingkungan bermain. Remaja semula bermain diluar rumah menjadi bermain didalam rumah. Sebagaimana contoh saat ini, banyak remaja yang bermain game di smartphone, menonton televisi, menggunakan komputer daripada berjalan, bersepeda maupun berolahraga. ${ }^{15}$ Penelitian yang dilakukan di SMA Negeri 5 Surabaya menunjukkan bahwa remaja tidak melakukan aktivitas fisik atau olahraga lainnya pada Sabtu dan Minggu sehingga aktivitas fisik mereka rendah. ${ }^{16}$

Menurut penelitian Silvia Etika Sari et.al. ${ }^{17}$, menyatakan bahwa terdapat hubungan aktivitas fisik dengan kejadian dismenore primer pada remaja putri. Sedangkan, menurut Tristiana $^{18}$, menyatakan bahwa tidak ada hubungan yang bermakna antara aktivitas fisik dengan dismenore primer pada santri . Berdasarkan hasil pemaparan yang berbeda dari beberapa jurnal maka perlu dilakukan suatu literature review untuk mengetahui hubungan aktivitas fisik dengan dismenore primer pada remaja secara bersamaan berdasarkan penelitian- penelitian yang telah dilakukan sebelumnya. Selain itu, belum ada publikasi literature review untuk mengenai hubungan aktivitas fisik dengan dismenore primer pada remaja.

\section{B. METODE PENELITIAN}

Systematic Literature Review adalah pendekatan yang digunakan dalam penelitian ini. Peneliti mengumpulkan data atau sumber dari berbagai kepustakaan seperti jurnal ilmiah dan artikel publikasi serta mengkaji dengan kritis temuan, pengetahuan atau gagasan pada komponen literature berpusat pada akademik disertai perumusan teoritis dan metodologis yang sesuai dengan varibel pada tema penelitian. ${ }^{19}$ Sumber data diperoleh dari jurnal-jurnal penelitian dalam rentang 5 tahun terakhir. yang membahas hubungan aktivitas fisik dengan dismenore primer pada remaja. Sumber jurnal nasional pada penelitian ini diperoleh dari Google Scholar dan Garuda, jurnal internasional diperoleh dari Google Scholar dan Science Direct. Peneliti memperoleh sumber data yang layak untuk direview berdasarkan kriteria inklusi dan eksklusi yang telah ditetapkan sebelumnya. Prosedur pengumpulan literature sesuai dengam Gambar 1. 


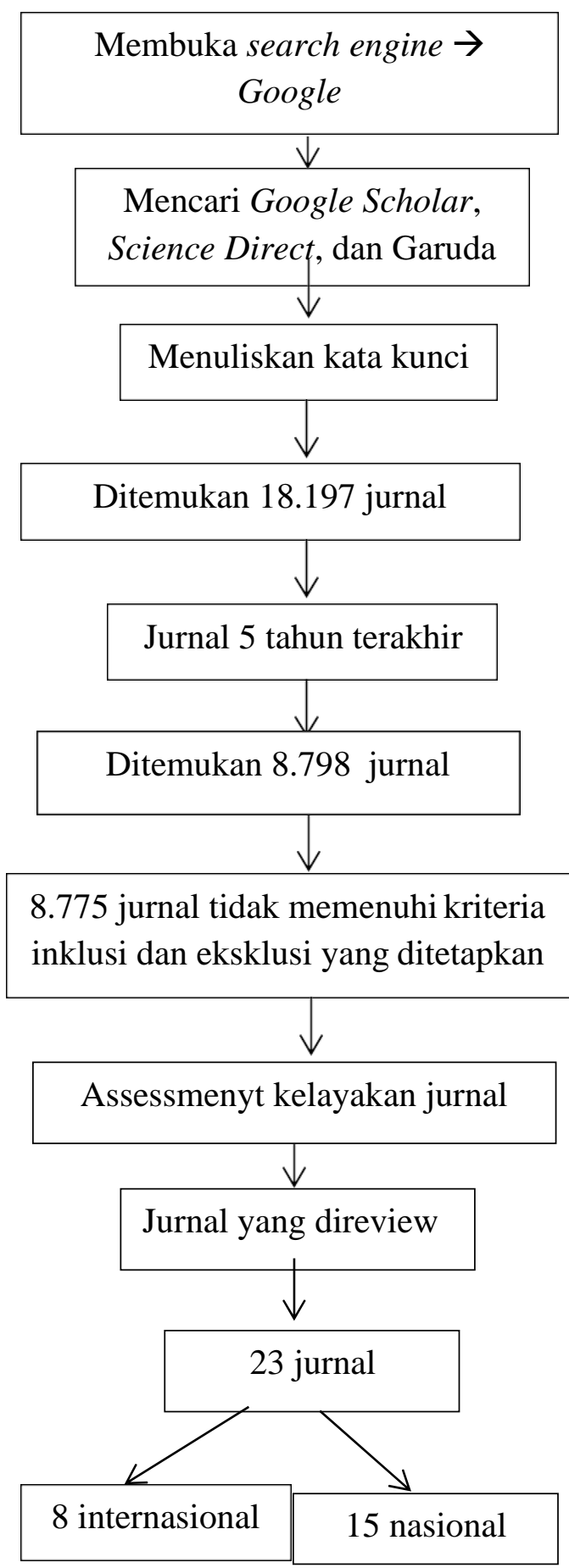

Gambar 1. Prosedur Pengumpulan Literature

\section{HASIL DAN PEMBAHASAN}

Literature review ini memperoleh data sekunder melalui database penyedia jurnal scientific Indonesia melalui Google Scholar dan jurnal internasional. Sintesis data pada literature review ini menggunakan naratif berdasarkan data yang telah dikelompokkan pada analisis kualitas data serta sesuai dengan kriteria inklusi peneliti untuk menjawab tujuan literature review. Jurnal yang sesuai dengan assessment kelayakan dan memenuhi kriteri inklusi maupun eksklusi diperoleh 23 jurnal, yaitu 15 jurnal nasional dan 8 jurnal internasional. Penelitian dari 15 jurnal nasional terdapat 13 jurnal yang menyatakan ada hubungan antara aktivitas fisik dengan dismenore primer pada remaja, sedangkan 2 jurnal nasional menyatakan tidak ada hubungan. Seluruh jurnal internasional yang berjumlah 8 jurnal menyatakan aktivitas fisik berhubungan dengan dismenore primer pada remaja. 
Tabel 1. Hasil Sintesis Data Jurnal Nasional dan Internasional

\begin{tabular}{|c|c|c|c|c|c|}
\hline No & Peneliti & Judul & Sampel & Metode & Output \\
\hline 1. & $\begin{array}{l}\text { Linda Ratna } \\
\text { Wati, Maya } \\
\text { Devi Arifiandi } \\
\text { dan Fatma } \\
\text { Prastiwi }\end{array}$ & $\begin{array}{l}\text { Hubungan Aktifitas Fisik } \\
\text { dengan Derajat } \\
\text { Dysmenorrhea } \text { Primer } \\
\text { pada Remaja }\end{array}$ & 52 & Prospektif & $\begin{array}{l}\text { Uji chi-square menunjukkan nilai } \\
\mathrm{p}=0,000 \text { sehingga menyatakan } \\
\text { bahwa ada hubungan aktivitas } \\
\text { fisik dengan dismenore primer } \\
\text { remaja. }\end{array}$ \\
\hline 2. & $\begin{array}{l}\text { Dian Islamiati, } \\
\text { Hendrik } \\
\text { Mentara, dan } \\
\text { Marhadi }\end{array}$ & $\begin{array}{l}\text { Hubungan Dismenore } \\
\text { Primer Terhadap } \\
\text { Aktivitas Olahraga } \\
\text { Remaja Putri di SMP } \\
\text { Negeri 1Banawa Tengah }\end{array}$ & 17 & $\begin{array}{l}\text { Cross } \\
\text { sectional }\end{array}$ & $\begin{array}{l}\text { Uji Kendal Tau nonparametric } \\
\text { menunjukkan nilai koefisien } \\
\text { relasi adalah } 0.000<0.05 \text {,artinya } \\
\text { terdapat hubungan yang } \\
\text { signifikan antara dismenore } \\
\text { primer dan aktivitas olahraga. }\end{array}$ \\
\hline 3. & $\begin{array}{l}\text { Amilia Azma, } \\
\text { Arif Tirtana dan } \\
\text { Maulida } \\
\text { Rahmawati } \\
\text { Emha }\end{array}$ & $\begin{array}{l}\text { Pengaruh Pemberian } \\
\text { Latihan Abdominal } \\
\text { Stretching terhadap } \\
\text { Penurunan Intensitas } \\
\text { Nyeri Haid (Dismenore) } \\
\text { pada Remaja Putri } \\
\text { STIKES Madani } \\
\text { Yogyakarta }\end{array}$ & 30 & $\begin{array}{l}\text { Quasy } \\
\text { eksperiment } \\
\text { dengan } \\
\text { pretest- } \\
\text { posttest with } \\
\text { control group. }\end{array}$ & $\begin{array}{l}\text { Uji wilcoxon menunjukkan bahwa } \\
\text { p=0,000. Nilai tersebut } \\
\text { memperlihatkan terdapat } \\
\text { perbedaan tingkatan nyeri haid } \\
\text { antara setelah dan sebelum } \\
\text { abdominal streatching pada } \\
\text { kelompok intervensi. }\end{array}$ \\
\hline 4. & $\begin{array}{l}\text { Linda Puspita } \\
\text { dan Tuti } \\
\text { Anjarwati }\end{array}$ & $\begin{array}{l}\text { Pengaruh Latihan } \\
\text { Abdominal Stretching } \\
\text { Terhadap Intensitas } \\
\text { Nyeri Haid pada Siswi } \\
\text { SMK Pelita } \\
\text { Gedongtataan Kabupaten } \\
\text { Pesawaran }\end{array}$ & 34 & $\begin{array}{l}\text { Pre- } \\
\text { eksperimen } \\
\text { dengan } \\
\text { pendekatan } \\
\text { one group } \\
\text { pretest } \\
\text { posttest design }\end{array}$ & $\begin{array}{l}\text { Uji wilcoxon menunjukkan bahwa } \\
\mathrm{p}=0,000 \text {. Nilai tersebut } \\
\text { memperlihatkan abdominal } \\
\text { stretching mempengaruhi } \\
\text { intensitas nyeri. }\end{array}$ \\
\hline 5. & $\begin{array}{l}\text { Anis Nikmatul } \\
\text { Nikmah }\end{array}$ & $\begin{array}{l}\text { Pengaruh Abdominal } \\
\text { Stretching Terhadap } \\
\text { Perubahan Nyeri } \\
\text { Dismenore Primer Pada } \\
\text { Remaja Putr }\end{array}$ & 16 & $\begin{array}{l}\text { Pre-ekspeimen } \\
\text { dengan one } \\
\text { group pre test } \\
\text { dan post test }\end{array}$ & $\begin{array}{l}\text { Uji wilcoxon menunjukkan bahwa } \\
\mathrm{p}=0,001 \text {. Nilai tersebut } \\
\text { memperlihatkan bahwa terdapat } \\
\text { perbedaan tingkatan nyeri setelah } \\
\text { abdominal stretching. }\end{array}$ \\
\hline 6. & $\begin{array}{l}\text { Yelmi Reni } \\
\text { Putri, Ratna } \\
\text { Dewi dan } \\
\text { Yuliani }\end{array}$ & $\begin{array}{l}\text { Efektifitas Pengaruh } \\
\text { Abdominal Streaching } \\
\text { Exercise Dan Kompres } \\
\text { Hangat Terhadap } \\
\text { Intensitas Nyeri } \\
\text { Dismenore }\end{array}$ & 20 & $\begin{array}{l}\text { Kuantitatif- } \\
\text { quasy } \\
\text { experiment } \\
\text { design dengan } \\
\text { pendekatan } \\
\text { two group } \\
\text { pretest- } \\
\text { posttest } \\
\text { design. }\end{array}$ & $\begin{array}{l}\text { Uji statistik menunjukkan bahwa } \\
\text { nilai } \mathrm{p}=0,001 \text {, berarti ada } \\
\text { pengaruh abdominal streaching } \\
\text { terhadap intensitas nyeri } \\
\text { dismenore. }\end{array}$ \\
\hline 7. & $\begin{array}{l}\text { Reza Elfira, Siti } \\
\text { Saadah,dan } \\
\text { Sariestya } \\
\text { Rismawati }\end{array}$ & $\begin{array}{l}\text { Pengaruh Pilates } \\
\text { Exercise Terhadap Nyeri } \\
\text { Primary Dismenore pada } \\
\text { Siswi di SMKN } \\
\text { Sukaresik Kabupaten } \\
\text { Tasikmalaya Tahun } 2017\end{array}$ & 100 & $\begin{array}{l}\text { Quasi } \\
\text { experiment } \\
\text { design with } \\
\text { time series } \\
\text { design }\end{array}$ & $\begin{array}{l}\text { Uji T memperlihatkan bahwa nilai } \\
\mathrm{p}=0,000 \text {, berarti pilates exercise } \\
\text { berpengaruh terhadap nyeri } \\
\text { dismenore. }\end{array}$ \\
\hline 8. & $\begin{array}{l}\text { Roihatul } \\
\text { Zahroh, Istiroha, } \\
\text { Natasya dan } \\
\text { Nadhita Larasati }\end{array}$ & $\begin{array}{l}\text { Pengaruh Senam } \\
\text { Dismenorrhea dan } \\
\text { Senam Aerobic Low } \\
\text { Impact Terhadap Nyeri } \\
\text { Haid (Dismenorrhea) } \\
\text { Pada Remaja Awal }\end{array}$ & 24 & $\begin{array}{l}\text { Pra } \\
\text { eksperimental } \\
\text { dengan } \\
\text { pendekatan } \\
\text { Pre Post Test } \\
\text { Two Group } \\
\text { Design. } \\
\end{array}$ & $\begin{array}{l}\text { Uji wilcoxon menunjukkan bahwa } \\
\text { nilai } \mathrm{p}=0,014 \text {, berarti ada } \\
\text { perbedaan intensitas dismenore } \\
\text { sesudah dengan sebelum senam } \\
\text { dismenore. }\end{array}$ \\
\hline
\end{tabular}


9. Ida Nurjanah, Yuniza dan

Miranti

Florencia Iswari

10. Wahyu Dwi Agussafutri dan Ika Budi Wijayanti

11. R. Tri Rahayuning Lestari, Ni Made Nopita Wati, I Gede Juanamasta, Ni Luh Putu Thrisnadewi dan Ni Komang Ayu Sintya Paramita

12. Yelva Febriani, SST.FT, M.Kes

13. Witri Hastuti dan Widiyaningsih

14. Rosvita, Novalia Clara., Widajanti, Laksmi., Pangestuti dan Dina Rahayuning

15. Fahimah, Ani Margawati dan
Pengaruh Senam

Dismenore Terhadap

Penurunan Nyeri

Menstruasi pada

Mahasiswi Asrama

STIKes Muhammadiyah

Palembang

Efektivitas Senam Haid

dalam Mengurangi

Intensitas Nyeri Haid

pada Mahasiswi

Kebidanan STIKES

Kusuma Husada

Surakarta

Pengaruh Terapi Yoga

(Paschimottanasana dan Adho Mukha

Padmasana) terhadap

Intensitas Nyeri pada

Remaja Putri yang

Mengalami Dismenore

Primer

Beda Pengaruh

Pemberian William's

Flexion Exercise dan

William's Flexion

Exercise dengan Kinesio

Tapping terhadap Nyeri

Dismenore

Senam Aerobic untuk

Mengatasi Nyeri

Menstruasi pada Remaja

Putri di Pondok

Pesantren Alishlah

Semarang

Hubungan Tingkat

Konsumsi Kalsium,

Magnesium, Status Gizi

(IMT/U), dan Aktivitas

Fisik dengan Kram Perut saat Menstruasi Primer pada Remaja Putri (Studi di Sekolah Menengah Atas Kesatrian 2 Kota Semarang Tahun 2017)

Hubungan Konsumsi Asam Lemak Omega-3,
34 Pre-

experiment menggunakan rancangan one group pretestposttest

$30 \quad$ Randomized Controlled Trial (RCT)

Quasi

eksperiment dengan rancangan pretestposttest with control group design.

Penelitian eksperimental dengan rancangan Two Group PretestPostest Design.

34 Eksperimental One groups Pre Test dan Post

52 Cross sectional sectional
Uji wilcoxon menunjukkan bahwa nilai $\mathrm{p}=0,005$, berarti , berarti ada perbedaan intensitas dismenore sesudah dengan sebelum aerobic low impact.

Dengan nilai median sebelum dan sesudah senam dismenore mengalami penurunan yang ditandai dengan nilai $\mathrm{p}=0,00$

Uji wilcoxon menunjukkan bahwa nilai $\mathrm{p}=0,001$, artinya senam haid dapat menurunkan intensitas nyeri haid.

Uji Paired T Test menunjukkan nilai $\mathrm{p}=0,001$, artinya ada perbedaan intensitas nyeri haid saat sebelum dan sesudah terapi yoga.

Nilai statistik untuk $\mathrm{p}=0,000$, berarti ada perbedaan intensitas penurunan nyeri menstruasi setelah melakukan William's Flexion Exersice dan William's Flexion Exercise dengan Kinesio Tapping.

Uji wilcoxon menunjukkan bahwa nilai $\mathrm{p}=0,000$, artinya senam aerobic menurunkan nyeri menstruasi pada remaja putri.

Uji chi square menunjukkan nilai $\mathrm{p}=1,00$, artinya tidak ada hubungan antara aktivitas fisik dengan kram perut saat menstruasi primer. 


\begin{tabular}{|c|c|c|c|c|c|}
\hline & $\begin{array}{l}\text { Deny Yudi } \\
\text { Fitranti }\end{array}$ & $\begin{array}{l}\text { Aktivitas Fisik dan } \\
\text { Persen Lemak Tubuh } \\
\text { dengan Tingkat } \\
\text { Dismenore pada Remaja }\end{array}$ & & & dengan dismenore. \\
\hline 16. & $\begin{array}{l}\text { Komang Agus } \\
\text { Jerry } \\
\text { Widyanata, I } \\
\text { Gede Yudiana } \\
\text { Putra, dan Putu } \\
\text { Intan } \\
\text { Daryaswanti }\end{array}$ & $\begin{array}{l}\text { Physical Activity and } \\
\text { Meditation to Reduce } \\
\text { Primary Dysmenorrhea } \\
\text { in Adolescent }\end{array}$ & 40 & $\begin{array}{l}\text { Quasi- } \\
\text { experimental } \\
\text { study with } \\
\text { nonrandomize } \\
\text { d pretest and } \\
\text { post-test } \\
\text { design }\end{array}$ & $\begin{array}{l}\text { Uji statistik wilcoxon signed rank } \\
\text { menunjukkan bahwa nilai } \\
\mathrm{p}<0,005 \text {, artinya ada penurunan } \\
\text { nyeri setelah melakukan aktivitas } \\
\text { fisik. }\end{array}$ \\
\hline 17. & $\begin{array}{l}\text { Tiyas } \\
\text { Kusumaningru } \\
\text { m, Aria Aulia } \\
\text { Nastiti, Lingga } \\
\text { Curnia Dewi } \\
\text { dan Aida } \\
\text { Lutfiani }\end{array}$ & $\begin{array}{l}\text { The Correlation between } \\
\text { Physical Activity and } \\
\text { Primary Dysmenorrhea } \\
\text { in Female Adolescents }\end{array}$ & 77 & $\begin{array}{l}\text { Cross } \\
\text { sectional }\end{array}$ & $\begin{array}{l}\text { Uji statistik menunjukkan bahwa } \\
\mathrm{p}=0,003 \text {, artinya aktivitas fisik } \\
\text { berhubungan dengan dismenore } \\
\text { pada remaja. }\end{array}$ \\
\hline 18. & $\begin{array}{l}\text { G.Tharani, } \\
\text { E.Dharshini, } \\
\text { V.Rajalaxmi, } \\
\text { K.Kamatchi dan } \\
\text { G.Vaishnavi }\end{array}$ & $\begin{array}{l}\text { To Compare the Effects } \\
\text { of Stretching Exercise } \\
\text { Versus Aerobic Dance in } \\
\text { Primary Dysmenorrhea } \\
\text { among Collegiates }\end{array}$ & 30 & $\begin{array}{l}\text { Pre- and post } \\
\text { comparative }\end{array}$ & $\begin{array}{l}\text { Uji statistik } T \text {-Test } \text { menunjukkan } \\
\text { bahwa nilai } \mathrm{p}=\leq 0,001 \text {, artinya } \\
\text { aerobic lebih efektif menurunkan } \\
\text { intensitas nyeri pada dismenore } \\
\text { primer. }\end{array}$ \\
\hline 19. & $\begin{array}{l}\text { Anuradha Sutar } \\
\text {, Sayli } \\
\text { Paldhikar, Nigar } \\
\text { Shikalgar, dan } \\
\text { Snehal Ghodey }\end{array}$ & $\begin{array}{l}\text { Effect of Aerobic } \\
\text { Exercises on Primary } \\
\text { Dysmenorrhoea in } \\
\text { College Students }\end{array}$ & 100 & $\begin{array}{l}\text { Randomized } \\
\text { Clinical Trial } \\
(R C T\end{array}$ & $\begin{array}{l}\text { Nilai statistik menunjukkan } \\
\text { bahwa nilai } \mathrm{p}<0,05 \text {, artinya } \\
\text { latihan aerobic dapat membantu } \\
\text { mengurangi rasa sakit pada } \\
\text { dismenore primer }\end{array}$ \\
\hline 20. & $\begin{array}{l}\text { Rashid } \\
\text { Heidarimoghada } \\
\text { m (PhD), } \\
\text { Elaheh } \\
\text { Abdolmaleki } \\
\text { (MSc), Farideh } \\
\text { Kazemi (PhD), } \\
\text { Seyedeh Zahra } \\
\text { Masoumi } \\
\text { (PhD), Batoul } \\
\text { Khodakarami } \\
\text { (MSc) dan } \\
\text { Younes } \\
\text { Mohammadi } \\
\text { (PhD) }\end{array}$ & $\begin{array}{l}\text { The Effect of Exercise } \\
\text { Plan Based on FITT } \\
\text { Protocol on Primary } \\
\text { Dysmenorrhea in } \\
\text { Medical Students: A } \\
\text { Clinical Trial Study }\end{array}$ & 86 & $\begin{array}{l}\text { Randomized } \\
\text { Clinical Trial } \\
(R C T)\end{array}$ & $\begin{array}{l}\text { Uji statistik menunjukkan bahwa } \\
\text { nilai } p=0,001 \text { artinya derajat nyeri } \\
\text { dan durasi nyeri berkurang atau } \\
\text { lebih rendah setelah latihan senam } \\
\text { FITT. }\end{array}$ \\
\hline 21. & $\begin{array}{l}\text { Reda Mohamed- } \\
\text { Nabil } \\
\text { Aboushady dan } \\
\text { Tawheda } \\
\text { Mohamed } \\
\text { Khalefa El- } \\
\text { saidy }\end{array}$ & $\begin{array}{l}\text { Effect of Home based } \\
\text { Stretching Exercises and } \\
\text { Menstrual Care on } \\
\text { Primary Dysmenorrhea } \\
\text { and Premenstrual } \\
\text { Symptoms among } \\
\text { Adolescent Girls }\end{array}$ & 80 & $\begin{array}{l}\text { Quasi- } \\
\text { experimental } \\
\text { research } \\
\text { design with } \\
\text { pre-posttest }\end{array}$ & $\begin{array}{l}\text { Uji statistik menunjukkan bahwa } \\
\text { nilai } \mathrm{p}=0,001 \text { artinya skor nyeri } \\
\text { sebelum menstruasi, sehari } \\
\text { setelah menstruasi, dan dua hari } \\
\text { setelah menstruasi berkurang } \\
\text { setelah melakukan latihan } \\
\text { peregangan dirumah. }\end{array}$ \\
\hline 22. & $\begin{array}{l}\text { Baiq Dewi } \\
\text { Sukma Septiani } \\
\text {, Adi Prayitno } \\
\text { dan Sugiarto }\end{array}$ & $\begin{array}{l}\text { Reducing primary } \\
\text { dysmenorrhea among } \\
\text { adolescent girls with } \\
\text { mung bean extract drinks }\end{array}$ & 58 & $\begin{array}{l}\text { Experimental } \\
\text { study of non- } \\
\text { randomized } \\
\text { controlled }\end{array}$ & $\begin{array}{l}\text { Uji statistik menunjukkan bahwa } \\
\text { nilai } \mathrm{p}=0,002 \text { untuk nyeri sedang } \\
\text { dan berat } \mathrm{p}=0.007 \text {. } \\
\text { Peregangan dapat menurunkan }\end{array}$ \\
\hline
\end{tabular}




\begin{tabular}{|c|c|c|c|c|c|}
\hline & & and stretching & & $\begin{array}{l}\text { trial open- } \\
\text { label with pre- } \\
\text { post design } \\
\text { research }\end{array}$ & $\begin{array}{l}\text { nyeri pada tingkat sedang dan } \\
\text { berat pada remaja. }\end{array}$ \\
\hline 23. & $\begin{array}{l}\text { Fatemeh Fallah } \\
\text { dan Mani } \\
\text { Mirfeizi }\end{array}$ & $\begin{array}{l}\text { How Is the Quality and } \\
\text { Quantity of Primary } \\
\text { Dysmenorrhea Affected } \\
\text { by Physical Exercises? A } \\
\text { Study Among Iranian } \\
\text { Students }\end{array}$ & 85 & $\begin{array}{l}\text { Randomized } \\
\text { Clinical Trial } \\
(R C T)\end{array}$ & $\begin{array}{l}\text { Uji statistik menunjukkan bahwa } \\
\text { PPI }(\mathrm{P}<0,005), \text { VAS }(\mathrm{p}<0,005), \\
\mathrm{TP}(\mathrm{p}<0,005) \text {, volme perdarahan } \\
(\mathrm{p}<0,005) \text {, dan panjang fase } \\
\text { menstruasi }(\mathrm{p}<0,005) \text {, artinya } \\
\text { terjadi penurunan pada PPI, VAS, } \\
\text { TP, volume perdarahan, dan } \\
\text { panjang fase menstruasi setelah } \\
\text { melakukan exercise. }\end{array}$ \\
\hline
\end{tabular}

Metode penelitian cross sectional digunakan oleh Rosvita Novalia et.al. ${ }^{20}$ dan Fahimah et.al. ${ }^{21}$ yang menyatakan tidak ada hubungan, sehingga subjek penelitian hanya diteliti sekali saja dan kurang dapat menggambarkan perkembangan penyakit secara akurat sehingga dapat mempengaruhi hasil penelitian. ${ }^{22}$ Peneliti memperoleh gambaran aktivitas fisik responden dengan menggunakan lembar recall 24 jam aktivitas fisik sehingga responden sulit mengingat dan menimbulkan bias pada hasil penelitian..$^{20}$ Ada faktor lain yang berhubungan dengan dismenore primer yaitu hormon prostaglandin yang dikeluarkan secara berlebihan karena faktor kongenital, usia haid pertama $<12$ tahun, status gizi, persen lemak pada tubuh, stress, dan kebiasaan mengkonsumsi asam lemak omega- $3 .{ }^{21}$

Berdasarkan 21 jurnal yang menyatakan ada hubungan antara kedua variabel, ada 4 jurnal membahas hubungan aktivitas fisik secara umum terhadap dismenore primer pada remaja. Penelitian yang dilakukan oleh Linda Ratna Wati et.al. ${ }^{23}$, Dian Islamiati et.al. ${ }^{24}$, Komang Agus Jerry et. al. ${ }^{25}$, dan Tiyas Kusumaningrum et.al. ${ }^{26}$, menyimpulkan bahwa aktivitas fisik dapat menurunkan intensitas nyeri menstruasi pada remaja. Ada 21 jurnal yang memaparkan bahwa aktivitas fisik sedang dapat meningkatkan sekresi hormon endorphin pada remaja, sehingga mencegah dan sekaligus mengobati dismenore primer pada remaja. ${ }^{27}$ Susunan dari 31 asam amino yang membentuk protein bertautan di otak disebut endorfin. Efek analgesia diperoleh dari ikatan antara beta endorfin dengan reseptor opioid pada ujung saraf pre dan post sinaps, dan terpenting pada presinap. Ikatan kaskade itu menyebabkan substansi $\mathrm{P}$ dan takinin terhambat sehingga tranmisi nyeri berkurang. GABA dihambat sehingga menghasilkan analgesik, sedangkan dopamin disekresikan. ${ }^{28,29}$

Selain itu, dari 21 jurnal tersebut diperoleh 8 jenis aktivitas fisik sedang yang dapat menurunkan dismenore primer pada remaja, antara lain: antara lain abdominal stretching, pilates exercise, yoga, william flexion exercise, senam dengan FITT, peregangan, aerobic, dan senam dismenore.
Abdominal stretching merupakan aktivitas fisik berdurasi 10 menit untuk kelenturan, kekuatan, serta daya tahan otot bagian perut. ${ }^{30}$ Jurnal nasional yang membahas pengaruh abdominal stretching terhadap dismenore primer ditemukan sebanyak 4 jurnal dan diteliti oleh Amilia Azma et.al..$^{30}$, Linda Puspita et.al. ${ }^{31}$, Anis Nikmatul Nikmah ${ }^{32}$, dan Yelmi Reni Putri et.al ${ }^{33}$, semuanya mengatakan ada hubungan. Abdominal stretching menyebabkan aliran darah kebagian genital meningkat, peningkatan endorpin lima kali lipat, serta pertukaran karbohidrat dan oksigen di jaringan. ${ }^{34}$

Penelitian yang berfokus pada hubungan pilates exercise dengan dismenore primer hanya diteliti oleh 1 jurnal nasional yaitu disusun oleh Reza Elfira et.al. ${ }^{35}$, menyatakan ada perubahan derajat nyeri dismenore dari intensitas sedang hingga ringan setelah dilakukan pilates exercise. Daerah antara punggung, pelvik, dan perut bagian bawah dapat ditingkatkan kebugarannya dengan melakukan pilates exercise sehingga aliran darah meningkat serta terjadi peningkatan endorphin. $35,36,37$

Ada 1 jurnal nasional yang meneliti hubungan yoga dengan dismenore primer pada remaja, disusun oleh R. Tri Rahayuning et.al ${ }^{38}$, menyimpulkan yoga paschimottanasana dan adho mukha padmasana berpengaruh secara signifikan terhadap intensitas nyeri dismenore primer. Paschimottanasana adalah gerakan yoga yang meningkatkan kesehatan sistem reproduksi, menguatkan bahu, otot perut, dan punggung. Adho Mukha Padmasana adalah gerakan yoga yang berpusat pada bagian bahu, paha, pinggul dan menurunkan stress. Kedua gerakan yoga menyebabkan vasodilatasi pembuluh darah, meningkatkan produksi endorpin, dan parasimpatis sehingga nyeri saat haid menjadi berkurang pada remaja. $38,39,40$

Terdapat hanya 1 jurnal nasional yang membahas pengaruh william flexion exercise dengan dismenore primer yaitu disusun oleh Yelva Febriani, ${ }^{41}$ menyebutkan bahwa nyeri menstruasi menurun setelah melakukan william's flexion exersice. Aktivitas fisik ini menyebabkan kontraksi otot perut dan lumbal bagian bawah, sehingga pembuluh darah yang berukuran besar menyalurkan aliran darah dengan lancar dan menghambat hipoksia jaringan. ${ }^{41}$ 
Ada 1 jurnal internasional yang meneliti keefektifan latihan senam FITT terhadap dismenore primer, yaitu disusun oleh Rashid Heidarimoghadam et.al. ${ }^{42}$, menyebutkan derajat nyeri dan durasi nyeri berkurang atau lebih rendah setelah latihan senam FITT. Olahraga ini dilakukan 3kali/minggu selama 8 minggu dengan jenis olahraga yang berbeda, setiap sesi latihan pertama dimulai dengan 20 menit, kemudian ditambah 2-3 menit hingga mencapai 47 menit. $^{42}$

Latihan peregangan merupakan aktivitas fisik yang berguna untuk merileksasikan otot dan ligament pada tubuh sehingga fleksibilitas otot tetap terjaga dan membantu menurunkan PGE2, sehingga penyempitan serviks dan pelepasan vasopresin terhambat. ${ }^{43,44}$ Terdapat 3 jurnal internasional yang membahas pengaruh peregangan terhadap dismenore primer, yaitu disusun oleh Reda dan Tawheda ${ }^{43}$, Baiq Dewi Sukma Septiani et.al. ${ }^{44}$, serta Fatemah dan Mani. Peregangan yang dilakukan 30 menit setiap hari dan dilakukan 7 hari sebelum menstruasi dapat meningkatkan sekresi endorphin tubuh. ${ }^{43,44}$

Aerobic exercise adalah olahraga terstruktur dengan memakai energi pembakaran, memerlukan oksigen, menyebabkan pembuluh darah elastis dan daya tampung jantung meningkat. ${ }^{45}$ Penelitian yang berfokus pada pengaruh aerobic terhadap dismenore primer berjumlah 2 jurnal, terdiri dari jurnal nasional dan internasional. Jurnal disusun oleh Witri dan Widiyaningsih ${ }^{46}$, serta Anuradha Sutar et.al. ${ }^{75}$. Senam aerobic selama 30 menit dengan frekuensi 2 kali dalam seminggu maka dapat mengurangi nyeri saat menstruasi ${ }^{46}$, sedangkan aerobic dengan durasi 10 menit selama 3 hari/minggu secara teratur dan disertai pendinginan dapat juga merilekskan otot perut menurunkan stress dan nyeri saat menstruasi. ${ }^{47}$

Senam dismenore berfokus pada area otot pinggang, panggul, serta perut. ${ }^{48}$ Jurnal nasional yang meneliti pengaruh senam dismenore terhadap dismenore primer pada remaja disusun oleh Ida Nurjanah et.al., ${ }^{48}$ dan Wahyu Dwi Agussafutri et.al. ${ }^{49}$, menyebutkan ada hubungan. Gerakan senam dismenore kedua jurnal terdiri dari 3 gerakan inti yaitu pemanasan, utama, serta relaksasi atau pendinginan. Senam ini menghasilkan hormon endorpin yang menurunkan nyeri saat haid..$^{50}$

Terdapat 1 jurnal nasional yang membandingkan efek senam dismenore dan aerobic low impact dengan dismenore primer pada remaja. Penelitian ini dilakukan oleh Roihatul Zahroh et.al. ${ }^{51}$, menyebutkan senam aerobic low impact lebih berpengaruh dibandingkan senam dismenore, alasannya senam aerobic low impact memiliki irama yang lebih lambat sehingga dapat diikuti oleh responden penelitian. ${ }^{51}$

Ada 1 jurnal internasional yang membandingkan latihan peregangan dengan aerobic terhadap dismenore primer, yang disusun oleh G. Tharani et.al. ${ }^{52}$ Hasil penelitian menyimpulkan jika aerobic lebih efektif secara signifikan daripada latihan peregangan

\section{KESIMPULAN}

Hasil penelitian pada 23 jurnal terdahulu membuktikan bahwa hubungan aktivitas fisik dengan dismenore primer pada remaja merupakan buki ilmiah yang kuat karena lebih banyak jurnal yang menyatakan ada hubungan antara kedua varibel. Aktivitas fisik sedang mempengaruhi dismenore primer karena meningkatkan sekresi endorphin (opiat alami), memperlancar pasokan aliran darah kebagian area genital remaja, merilekskan otot-otot perut, dan meningkatkan vasodilatasi pembuluh darah, sehingga menyebabkan penurunan nyeri menstruasi pada remaja. Jenis aktivitas fisik yang dimaksud adalah aktivitas fisik sedang dapat mencegah serta mengobati dismenore primer pada remaja.

Hasil literature review ini dapat dijadikan sumber kepustakaan bagi penelitian selanjutnya, namun perlu ditambahkan jumlah jurnal yang lebih banyak sebagai sumber data sekunder, mencantumkan jenis aktivitas fisik lain yang berhubungan dengan aktivitas fisik pada remaja, serta mengaitkan variabel lain yang berkaitan dengan dismenore primer pada remaja.

\section{DAFTAR PUSTAKA}

1. World Health Organization. Disminorea. 2010

2. Nurwana N, Sabilu Y, Fachlevy A. Analisis Faktor Yang Berhubungan Dengan Kejadian Disminorea Pada Remaja Putri Di SMA Negeri 8 Kendari Tahun 2016. Jurnal Ilmiah Mahasiswa Kesehatan Masyarakat Unsyiah. 2017;2(6):185630.

3. Dewi NS. Biologi Reproduksi. Yogyakarta: Pustaka Rihama, 2012.

4. Sinha S, Srivastava J, Sachan B, Singh R. A Study of Menstrual Pattern and Prevalence of Dysmenorrhea During Menstruation Among School Going Adolescent Girls in Lucknow District, Uttar Pradesh, India. Internationl Journal Community Medicine Public Health. 2016;3(5):1200-3.

5. Larasati T, Alatas F. Dismenore Primer dan Faktor Risiko Dismenore Primer pada Remaja. Majority. 2016;5(3):79-84.

6. Ammar UR. Faktor Risiko Dismenore Primer pada Wanita Usia Subur di Kelurahan Ploso Kecamatan Tambaksari Surabaya. Jurnal Berkala Epidemiologi. 2016;4(1):37-49.

7. Habibi N, Huang MSL, Gan WY, Zulida R, Safavi SM. Prevalence of Primary Dysmenorrhea and Factors Associated with Its Intensity Among Undergraduate Students: A Cross-Sectional Study. Pain Management Nursing. 2015;16(6):855-61.

8. Gulzar S, Khan S, Abbas K, Arif S, Husain SS, Sommer J. Prevalence, Perceptions and Effects 
of Dysmenorrhea in School Going Female Adolescents of Karachi , Pakistan. International Journal Innovative Research and Development. 2015;4(2):236-40.

9. Lghoul S, Loukid M, Hilali MK. Prevalence and Predictors of Dysmenorrhea Among a Population of Adolescent's Schoolgirls (Morocco). Saudi Journal of Biological Sciences [Internet]. 2020. [cited 2020 Jun 16]. Available from: https://doi.org/10.1016/j.sjbs.2020.05.022

10. Prawirohardjo S. Ilmu Kebidanan Edisi Ketiga. Jakarta: Yayasan Bina Pustaka, 2007.

11. Chang, Esther, Daly, John, Elliott D. Patofisiologi Aplikasi Praktik Keperawatan. Jakarta: Penerbit Buku Kedokteran EGC; 2010.

12. Anindita P, Darwin E, Afriwardi A. Hubungan Aktivitas Fisik Harian dengan Gangguan Menstruasi pada Mahasiswa Fakultas Kedokteran Universitas Andalas. Jurnal Kesehatan Andalas. 2016;5(3):522-7.

13. Ju H, Jones M, Mishra G. The Prevalence and Risk Factors of Dysmenorrhea. Epidemiologic Reviews. 2014;36(1):104-13.

14. Joshi T, Patil A, Kural M, Noor N, Pandit D. Menstrual Characteristics and Prevalence of Dysmenorrhea in College Going Girls. Journal of Family Medicine and Primary Care. 2015;4(3):426.

15. Kusuma BP. Hubungan Aktivitas Fisik dengan Dismenore Primer pada Remaja Putri di Desa Lerep Kecamatan Ungaran Barat. SSRN Electronic Journal. 2019;5(564):1-19.

16. Putra WN. Hubungan Pola Makan, Aktivitas Fisik dan Aktivitas Sedentari dengan Overweight di SMA Negeri 5 Surabaya. Jurnal Berkala Epidemiologi [Internet]. 2018.[cited 2020 Jun 16] ;298-382.Available from: https://www.researchgate.net/publication/322591 $\underline{609}$

17. Sari SE, Kartasurya MI, Pangestuti DR. Anemia Dan Aktivitas Fisik Yang Ringan Mempengaruhi Faktor Risiko Dismenore Pada Remaja Putri. Jurnal Kesehatan Masyarakat. 2018;6(5):437-44.

18. Tristiana A. Hubungan Aktivitas Fisik Dengan Kejadian Dismenore Primer pada Santri Di Pondok Pesantren X Di Kabupaten Bogor. Jurnal Keperawatan. 2017;1:93.

19. Marzali A. Menulis Kajian Literatur. 1st ed. Journal Etnografi Indonesia. 2017. 27 p.

20. Rosvita NC, Widajanti L, Pangestuti DR, Rosvita NC. Hubungan Tingkat Konsumsi Kalsium, Magnesium, Status Gizi (Imt/U), Dan Aktivitas Fisik Dengan Kram Perut Saat Menstruasi Primer Pada Remaja Putri (Studi Di Sekolah Menengah Atas Kesatrian 2 Kota Semarang Tahun 2017). Jurnal Kesehatan Masyarakat. 2018;6(1):519-25.
21. Famimah F, Margawati A, Fitranti DY. Hubungan Konsumsi Asam Lemak Omega-3, Aktivitas Fisik Dan Persen Lemak Tubuh Dengan Tingkat Dismenore Pada Remaja. Journal of Nutrition College. 2017;6(4):268.

22. Nurdini A. Cross Sectional vs Longitudinal: Pilihan Rancangan Waktu Dalam Penelitian PerumahanPermukiman. Jurnal Dimensi Teknik Arsitektur.2006:34(1);52-58

23. Wati LR, Arifandi MD, Prastiwi F. Hubungan Aktifitas Fisik dengan Derajat Dysmenorrhea Primer pada Remaja. Journal of Issues In Midwifery. 2017;1(2):1-8.

24. Islamiati, Dian, Mentara H. Hubungan Dismenore Primer Terhadap Aktivitas Olahraga Remaja Putri di SMP Negeri 1 Banawa Tengah. Tadulako Journal Sport Sciences and Physical Education. 2019;7(1):52-66.

25. Widyanata KAJ, Putra IGY, Daryaswanti PI. Physical Activity And Meditation To Reduce Primary Dysmenorrhea In Adolescent. 2017;3(Inc):18-20.

26. Kusumaningrum T, Nastiti AA, Dewi LC, Lutfiani A. The Correlation Between Physical Activity and Primary Dysmenorrhea in Female Adolescents. Indian Journal of Public Health Research and Development. 2019;10(8):255963.

27. CDC. Center for Disease Control Adults Physical Activity Questions on the National Health Interview Survey [Internet]. 2012. Available from: http://www.cdc.gov/nchs/nhis/physical_activity/ pa guide.htm

28. Indah, Mutiara. 2004. Mekanisme Kerja Hormon. Universitas Sumatera Utara. USU digital library pp.1-26

29. Anwar, R. 2005. Sekresi Gonadotropin Hypofise. Universitas Padjajaran.pp.1-22

30. Azma A, Tirtana A, Maulida Rahmawati Emha. Pengaruh Pemberian Latihan Abdominal Stretching Terhadap Penurunan Intensitas Nyeri Haid (Disminore) Pada Remaja Putri Stikes Madani Yogyakarta. Jurnal Kesehatan Madani Medika. 2018;9(2):12-8.

31. Puspita L, Anjarwati T. Pengaruh Latihan Abdominal Stretching Terhadap Intensitas Nyeri ntensitas Nyeri Haid pada Siswi SMK Pelita Gedongtataan Kabupaten Pesawaran. Wellness Healthy Magazine. [Internet]. 2019. [cited 2020 Oct 12]. Available from: https://wellness.journalpress.id/wellness/

32. Nikmah AN. Pengaruh Abdominal Sretching Terhadap Perubahan Nyeri Dismenorea Primer Pada Remaja Putri. Journal of Chemical Information and Modeling. 2019;53(9):1689-99.

33. Putri YR, Dewi R, Yuliani Y. Efektifitas Pengaruh Abdominal Streaching Exercise Dan 
Kompres Hangat Terhadap Intensitas Nyeri Dismenore. Real in Nursing Journal. 2019;2(1):38.

34. Putri YR, Dewi R, Yuliani Y. Efektifitas Pengaruh Abdominal Streaching Exercise Dan Kompres Hangat Terhadap Intensitas Nyeri Dismenore. Real in Nursing Journal. 2019;2(1):38.

35. Elfira R. Pengaruh Pilates Exercise Terhadap Nyeri Primary Dysmenorrhea Pada Siswi Di Smkn Sukaresik Kabupaten Tasikmalaya Tahun 2017. Jurnal Kesehatan Bakti Tunas Husada: Jurnal Ilmu-Ilmu Keperawatan, Analis Kesehatan dan Farmasi. 2018;17(2):293.

36. Murti OS. Perbedaan Pengaruh Peningkatan Fleksibilitas Back Muscle Dengan Latihan Pnf Stretching Dan Pilates Exercise Pada Wanita.[Skripsi] Jakarta: Universita Esa Unggul; 2016.

37. Trisnowiyanto B. Pengaruh Mat Pilates Exercise Terhadap Fleksibilitas Tubuh. Jurnal Kesehatatan. 2017;9(2):40.

38. Lestari RTR, Made N, Wati N, Juanamasta IG, Luh N, Thrisnadewi $\mathrm{P}$, et al. Pengaruh Terapi Yoga ( Paschimottanasana dan Adho Mukha Padmasana ) terhadap Intensitas Nyeri pada Remaja Putri yang Mengalami Dismenore Primer The Effect of Yoga Therapy ( Paschimottanasana and Adho Mukha Padmasana ) on Pain Intensity in Adolescence Girl. Journal of Health Science and Prevention. 2019;3(2):957.

39. Amalia A. Tetap Sehat Dengan Yoga. Jakarta: Panda Medika; 2015.

40. Bali DKP. Angka Kejadian Dismenore. 2014.

41. Febriani Y. Beda Pengaruh Pemberian William's Flexion Exercise dan William Flexion Exercise dengan Kinesio Tapping Terhadap Nyeri Dismenore. Jurnal Penelitian dan Kajian Ilmu. 2019;13(6):297-303.

42. Heidarimoghadam R, Abdolmaleki E, Kazemi F, Masoumi SZ, Khodakarami B, Mohammadi Y. The effect of exercise plan based on FITT protocol on primary dysmenorrhea in medical students: A clinical trial study. Journal of Research in Health Sciences. 2019;19(3).

43. Aboushady RM, El-saidy TMK. Effect of Home based Stretching Exercises and Menstrual Care on Primary Dysmenorrhea and Premenstrual Symptoms among Adolescent Girls. Journal of Nursing Health and Science. 2016;5(2):10-7.

44. Septiani BDS, Prayitno A, Sugiarto S. Reducing Primary Dysmenorrhea Among Adolescent Girls with Mung Bean Extract Drinks and Stretching. International Journal of Public Health Science. 2018;8(1):58.

45. Palar CM, Wongkar Djon, Ticoalu SHR. Manfaat Latihan Olahraga Aerobik Terhadap
Kebugaran Fisik Manusia Fakultas Kedokteran Universitas Sam Ratulangi Manado. Jurnal eBiomedik. 2015;3(1):316-21.

46. Hastuti W, Widiyaningsih W. Senam Aerobic Untuk Mengatasi Nyeri Menstruasi Pada Remaja Putri Di Pondok Pesantren Al Ishlah Semarang. Jurnal Kesehatan Kusuma Husada. 2020;86-90.

47. Sutar A, Paldhikar S, Shikalgar N, Ghodey S. Effect of Aerobic Exercises on Primary Dysmenorrhoea in College Students. IOSR Journal of Nursing Health and Science. 2016;05(05):20-4.

48. Nurjanah I, Iswari MF. Pengaruh Senam Dismenore Terhadap Penurunan Nyeri Menstruasi pada Mahasiswi Asrama STIKes Muhammadiyah Palembang. Syifa'Medika. 2019;10(1).

49. Agussafutri, Dwi W, Wijayanti, Budi I. Efektivitas Senam Haid Dalam Mengurangi Intensitas Nyeri haid pada Mahasiswi Prodi DIII Kebidanan STIKES Kusuma Husada Surakarta. Jurnal Kesmadaska. 2016;1:108-12.

50. Ramaiah. Pengantar Keperawatan Profesional. Jakarta: EGC; 2012.

51. Ezalia E, R IE, Elizabeth G, My WANH, Norhanim A, Wahidah A, et al. Pengaruh Senam Dismenorhhea Dan Senam Aerobic Low Impact Terhadap Nyeri Haid (Dismenorrhea) Pada Remaja Awal. Orphanet Journal of Rare Disease. 2020;21(1):1-9.

52. Tharani G, Dharshini E, Rajalaxmi V, Kamatchi K, Vaishnavi G. To Compare The Effects of Stretching Exercise Versus Aerobic Dance in Primary Dysmenorrhea Among Collegiates. Drug Invent Today. 2018;10(Special Issue 1):2844-8 
